\title{
The Alpine Wilson cycle and NW Tethyan Metallogeny
}

\author{
doi: $10.4154 / \mathrm{gc} .2016 .01$
}

\section{Editorial}

\section{Dear readers,}

This issue of Geologia Croatica (The Alpine Wilson cycle and NW Tethyan Metallogeny) is devoted to Ivan Jurković, a professor emeritus of Economic geology (Ore petrology) and Ore microscopy at the Faculty of Mining, Geology and Petroleum Engineering and the former Rector of the University of Zagreb, who passed away on the $30^{\text {th }}$ December, 2014. More about his life and an extensive bibliography can be found in In Memoriam at the end of this issue.

His fruitful and productive life was characterized by full devotion to science and care for education of generations of geologists. Geological investigations of Prof. Jurković cover, beside all republics of the former state, a vast global territory in Africa, Asia and South America. In educational, social, and political domain he served many highly ranked duties.

Ivan Jurković is a founder of modern studies in the field of ore genesis and metallogeny in Croatia. His scientific credo, as a ground of research credibility urged to join different geological disciplines into a complex subject of Science of ore deposits. He recognized, in his early research days, importance of symbiosis of regional geology and ore genesis, termed metallogeny.

In the century of revolutionary affirmation of global tectonics as deus ex machina of orogenesis, Ivan Jurković without hesitation accepted its principles and bravely incorporated Wilson cycle into the studies of ore deposits in Dinarides. As his successors, we try to follow a backbone of his fruitful ideas and research philosophy. In the coming years new generation of researcher keeps in line with the track routed by his principles.

This issue is a selection of papers on genesis of ore deposits in the NW Tethyan domain from Alps, Dinarides, Carpathians and Hellenides. Submitted papers bring results of new research, but also valuable reviews, collection of long-time experience about the theme close to life-time interest of professor Ivan Jurković in behalf of memories to this extraordinary scientist.

The choice of subjects is tightly leaned to synthesis of regional geology, petrology, and geochemistry, serving as a ground for modelling genesis of ore deposits. The following papers give an overwiev in discourse with the phases of Wilson cycle in the evolution of the NW Tethyan metallogeny, from the incipient rifting to the collision of the two immense continental blocks Gondwana and Eurasia.

The rifting phase assumes a half of the total duration of the Wilson cycle. It started in the Middle Permian and continued till the end of the Triassic, gradually developing into the pelagic environment underlain by an oceanic crust. The rifting itself is divided into two phases with distinguished characteris- tics, the Early intra-continental rifting and the Advanced rifting stage. However, this important distinction is usually not enough recognized or appreciated. Their diversification brings plethora of phenomena in tectonism, magmatism, sedimentary facies and ore deposit formation. The ore deposits related to early intra-continental rifting were exemplified by paper Palinkaš et al.: The Ljubija geothermal field, a herald of the Pangea break-up (NW Bosnia and Herzegovina). A fascinating similarity between the siderite and magnesite deposits in the Alps and those in Dinarides, are their features which provoke a similar genetic model: high heat flow in the rift-environment which induced hydrothermal convection systems and mobilized the residual evaporitic brines. Lithospheric extension and long-lasting thermal activity related to igneous and metamorphic activities are documented in the basement rocks of the Adriatic plate, as stated in the paper presented by Prochaska: Genetic concepts on the formation of the Austrian magnesite and siderite mineralizations in the Eastern Alps of Austria.

Advanced rifting setting in Middle Triassic times is characterised by submarine volcanism, with immense pillow lava facies, and related hydrothermal processes. Comparative studies on hydrothermal alteration of submarine peperitic basalt are described in details by Kiss et al.: Hydrothermal processes related to Triassic and Jurassic submarine basaltic complexes in northeastern Hungary and in the Dinarides and Hellenides.

Basaltic volcanism is accompanied by formation of sedimentary-exhalative (SEDEX) deposits in the developing rifting basin adjacent to Moesian carbonate platform. The carbonate platform itself hosts stratiform-stratabound base metal deposits with characteristics of Mississippi Valley Type (MVT) deposits, or Bleiberg-Mežica types in the Alps presented by Marinova \& Damyanov: The Triassic carbonate-hosted stratiform-stratabound base-metal deposits in the Western Balkan, NW Bulgaria - Plate tectonics aspects.

Advanced rifting stage in Middle Triassic time proceeded by formation of a deep marine basin and divergent drifting of the passive continental margins already flanked by the newly formed Dinaridic and Moesian carbonate platforms. This is the scenario for genesis of the two contemporaneous types of deposits, SEDEX in the rift and MVT within the carbonate platforms facing each other on the opposite sides. Recognition of this simple pairing mechanism by metallogenic patterns speaks in favour of the one ocean model in the early age of the Tethyan history as imparted in the text by Palinkaš et al.: Diverging drifting of Adriatic-Dinaridic and Moesian carbonate platforms during rifting phase witnessed by Triassic $M V T \mathrm{~Pb}-\mathrm{Zn}$ and SEDEX deposits; Metallogenic approach.

Intraoceanic subduction ocean-ocean setting in the NeoTethys in Upper Jurassic time is a turnover of extensional into compressional regime and beginning of the ocean closure. At the same time obduction of the overriding oceanic plate marks 
the formation of the mélange, transfer of the obduction pressure onto the carbonate platform and progress of its tectonic bulging from the platform margin to the hinterland. It generated exposure of the drylands from the Middle Cretaceous to the Paleogene as the most productive period of bauxite formation and the time of its influence on global climates and greenhouse effects. The bauxite formation as an inexhaustible repository of information on global climates is expressed in the paper Mindszenty: Bauxites: Feedbacks of System Earth at Greenhouse times.

One of the possible and probable candidates for subduction ocean-continent setting in the NW Tethys is subsidence of the Vardar oceanic crust beneath the Serbo-Macedonian continental mass. One of the convincing evidence is paroxysm of calc-alkaline magmatism typical products of arc-volcanism during the Lower Cretaceous in the Timok area. It nested numerous morphogenetic types of ore deposits, with rich mineral and metal paragenesis. A review paper of Jelenkovic et al.: The Mineral Resources of the Bor Metallogenic Zone, A Review, summarizes major genetic ore morphotypes in this unique metallogenic zone, a natural laboratory for interplay of magmatic heat and fluid rock interaction.

Collision and post-collision continent-continent setting is presented by four papers. Igneous Cenozoic rocks of the Serbian part of the Balkan Peninsula are emplaced along a mega-suture that is left behind after the closure of Neotethys Ocean. From the metallogenic point of view the Lower Cretaceous subduction related magmatism, induced by subsidence of Vardar oceanic crust beneath the Serbo-Macedonian continental block, was the most productive in the NW Tethys history. The following scenarios mark a long retreat of the subduction slab to the west. It was going on by melting of a heterogeneous mantle during compressional regime, and succeeding decompression which increased contribution of crustal melts and enhanced its alkaline character. Engagement of the crust caused enrichment of crustal metals, what resulted in creation of impressive metallogenic belt of Dinarides presented by Cvetković et al.: The Rudnik Mts. volcano-intrusive complex (Central Serbia): an example of how magmatism controls metallogeny.

The Bučim ore deposit belongs to the Lece-Chalkidiki metallogenic zone as a part of the Serbo-Macedonian metallogenic province. It was developed at the contact of the ensialic SerboMacedonian block and tectonically unstable Vardar zone. The ore deposits are related to post-collisional intermediary calc-alkaline magmatism of Neogene age. The metallogeny of the Lece-Chalkidiki zone is characterized by crustal elements $\mathrm{Pb}$ $\mathrm{Zn}-\mathrm{Sb}$. Porphyry copper deposits in the Bučim ore field of the
Lece-Chalkidiki zone represent an individual metallogenic unit with a clear metal zoning. Dominance of copper among the metals is inheritance from ophiolites underlying the host crystalline rocks of Serbo-Macedonian massif. The Detailed description of the Bučim ore field is given by Serafimovski et al.: Porphyry $\mathrm{Cu}$ mineralizations related with the small Tertiary volcanic intrusions in the Bučim ore deposit, Eastern Macedonia.

The Trepča Pb-Zn-Ag skarn deposit, Kosovo, is a part of the Serbo-Macedonian metallogenic province, at the border with the Lece-Chalkidiki metallogenic zone. Trepča is a typical product of post-collisional magmatic activation generating potassic to ultrapotassic magma, with strongly variable petrography. The magmatism and volcanism in the area was controlled by instability of the complex Dinaride-Hellenide orogen. The region of Trepča deposit in the Oligocene time was a site of frequent volcanic vent eruptions and maar-type phreatomagmatic explosion, what resulted in extensive hydraulic bracciations, important feature in the genetic evolution of the mineralization. Phreatomagmatic explosions and formation of the breccia turned the system from lithostatic to hydrostatic regime and triggered retrograde stage increasing water activity and oxygen fugacity in the system described in Strmić Palinkaš et al.: Origin and K-Ar age of the phreatomagmatic breccia at the Trepča Pb-Zn-Ag skarn deposit, Kosovo: Implications for ore-forming processes.

The most remarkable magmatic activity in Paleogene-Neogene times is in the Periadriatic-Sava-Vardar Zone, which follows the Periadriatic lineament in the Alps, and continuous into the Dinarides and Hellenides and marks closure of the Neotethyan Ocean and its slivers as Central Vardar ophiolite, West Vardar ophiolite and Dinaride ophiolite belts. The Priabonian-Neogenic magmatic activity in continuation is a generously productive metallogenic phase. It took place after the collisional processes in the Balkanide-Dinarides during the Middle Eocene and accommodates Serbo-Macedonian Metallogenic Province. The extension of the Neogene metallogeny crosses the border between the Serbo-Macedonian and Southern Rhodopian formations in the Thrace as the Rhodope metallogenic province. The review paper of Melfos \& Voudouris: Fluid evolution in Tertiary magmatic-hydrothermal ore systems at the Rhodope metallogenic province, NE Greece, focuses on the nature, composition and origin of magmatic-hydrothermal ore forming fluids involved in the formation of representative Tertiary ore deposits at the Rhodope metallogenic province in NE Greece.

This issue dedicated to late professor emeritus Ivan Jurković is a tribute to his significant contribution and presentation of nowadays development of idea he initiated.

Ladislav A. Palinkaš, Issue Editor

Vladimir Bermanec, Issue Editor Lidija Galović, Editor-in-Chief 